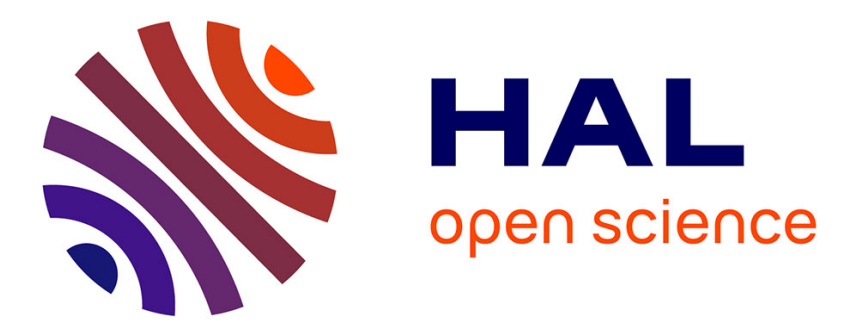

\title{
Evolution of salinity tolerance in the diving beetle tribe Hygrotini (Coleoptera, Dytiscidae)
}

Adrián Villastrigo, Hans Fery, Michael Manuel, Andrés Millan, Ignacio Ribera

\section{To cite this version:}

Adrián Villastrigo, Hans Fery, Michael Manuel, Andrés Millan, Ignacio Ribera. Evolution of salinity tolerance in the diving beetle tribe Hygrotini (Coleoptera, Dytiscidae). Zoologica Scripta, 2018, 47 (1), pp.63-71. 10.1111/zsc.12255 . hal-01744452

\section{HAL Id: hal-01744452 https://hal.sorbonne-universite.fr/hal-01744452}

Submitted on 27 Mar 2018

HAL is a multi-disciplinary open access archive for the deposit and dissemination of scientific research documents, whether they are published or not. The documents may come from teaching and research institutions in France or abroad, or from public or private research centers.
L'archive ouverte pluridisciplinaire HAL, est destinée au dépôt et à la diffusion de documents scientifiques de niveau recherche, publiés ou non, émanant des établissements d'enseignement et de recherche français ou étrangers, des laboratoires publics ou privés.

\section{(c)(1)}

Distributed under a Creative Commons Attribution| 4.0 International License 


\title{
Evolution of salinity tolerance in the diving beetle tribe Hygrotini (Coleoptera, Dytiscidae)
}

\author{
Adrián Villastrigo $^{1}$ | Hans Fery $^{2}$ | Michaël Manuel $^{3}$ | Andrés Millán ${ }^{4}$ | \\ Ignacio Ribera $^{1}$ (1)
}

${ }^{1}$ Institute of Evolutionary Biology (CSICUniversitat Pompeu Fabra), Barcelona, Spain

${ }^{2}$ Räuschstraße 73, Berlin, Germany

${ }^{3}$ UPMC Univ Paris 06, CNRS, Evolution Paris-Seine UMR7138, Institut de Biologie Paris-Seine, Sorbonne Universités, Paris, France

${ }^{4}$ Department of Ecology and Hydrology, University of Murcia, Murcia, Spain

\section{Correspondence}

Ignacio Ribera, Institute of Evolutionary Biology (CSIC-Universitat Pompeu Fabra), Barcelona, Spain.

Email: ignacio.ribera@ibe.upf-csic.es

\section{Funding information}

Ministerio de Economía y Competitividad, Grant/Award Number: CGL2013-48950-

C2-1-P and CGL2013-48950-C2-2-P; FPI Grant/Award Number: BES-2014-069398
Some species of the diving beetle tribe Hygrotini (subfamily Hydroporinae) are among the few insects able to tolerate saline concentrations more than twice that of seawater. However, the phylogenetic relationships of the species of Hygrotini, and the origin and evolution of tolerance to salinity in this lineage, are unknown. In this work, we aim to reconstruct how many times salinity tolerance did evolve in Hygrotini, whether this evolution was gradual or if tolerance to hypersalinity could evolve directly from strictly freshwater (FW) species, and to estimate the probabilities of transition between habitats. We build a phylogeny with ca. $45 \%$ of the 137 species of Hygrotini, including all major lineages and almost all of the known halophile or tolerant species. We used sequence data of four mitochondrial (COI-5', COI$3^{\prime}, 16 \mathrm{~S}+$ tRNA and NADH1) and three nuclear $(28 \mathrm{~S}, 18 \mathrm{~S}$ and H3) gene fragments, plus ecological data to reconstruct the history of the salinity tolerance using Bayesian inference. Our results demonstrate multiple origins of the tolerance to salinity, although most saline and hypersaline species were concentrated in two lineages. The evolution of salinity was gradual, with no direct transitions from FW to hypersaline habitats, but with some reversals from tolerant to FW species. The oldest transition to saline tolerance, at the base of the clade with the highest number of saline species, was dated in the late Eocene-early Oligocene, a period with decreasing temperature and precipitation. This temporal coincidence suggests a link between increased aridity and the development of tolerance to saline waters, in agreement with recent research in other groups of aquatic Coleoptera.

\section{1 | INTRODUCTION}

Hydroporinae is the most diverse of the subfamilies of diving beetles (Dytiscidae) (Nilsson \& Hájek, 2017a) and its species also display a large variety of ecologies and life habits (Miller \& Bergsten, 2016). Many species of Hydroporinae live in extreme or unusual environments for diving beetles, such as subterranean aquifers, forest litter or hypersaline waters. While the origin and evolution of subterranean and terrestrial lifestyles have received recent attention (e.g., Leys \& Watts, 2008; Tierney et al., 2015; Toussaint, Hendrich, Escalona, Porch, \& Balke, 2016), the origin of the species of diving beetles able to sustain extreme salt concentration has never been addressed in a phylogenetic context, whereas for other families of aquatic Coleoptera, such as Hydrophilidae or Hydraenidae, comparative studies on the evolution of saline tolerance are already available (Arribas et al., 2014; Sabatelli et al., 2016).

Within Hydroporinae, species which are exclusively halophile or which can tolerate saline or hypersaline waters have independently evolved in three tribes, Bidessini, Hydroporini and Hygrotini (Miller \& Bergsten, 2016). The latter includes some of the most extreme examples of saline tolerance, with some species able to sustain concentrations above $70 \mathrm{~g} / \mathrm{L}$, twice that of seawater (Picazo, Moreno, \& Millán, 2010; Timms \& Hammer, 1988). The physiological mechanism of 
salt tolerance of Hygrotus (Coelambus) salinarius (Wallis, 1924) has been studied by Tones (1978). However, the species' phylogenetic relationships are unknown, and in consequence whether it may be related to other saline tolerant species of Hygrotus Stephens, 1828 or what could have been the origin of its saline tolerance.

With this work we aim to investigate the phylogenetic relationships among salt tolerant species of Hygrotini, and their relationships with the rest of the species of the tribe. This will allow to answer some basic questions such as: (i) how many times did salinity tolerance evolve in Hygrotini? (ii) was this evolution gradual (i.e., from FW to intermediate salinities to hypersaline), or could tolerance to hypersalinity have evolved directly from strictly FW species? (iii) which were the probabilities of transitions between habitats in the evolution of Hygrotini? and (iv) are there any general patterns in the geographic and temporal origin of salinity tolerance in Hygrotini?

To answer these questions we built a molecular phylogeny with almost half of the 137 known species of the tribe, including all genera and recognised main species groups (Nilsson \& Hájek, 2017a,b), and compiled data on the ecological tolerances of all described species from the literature and our own observations. In addition, our results demonstrated that two of the four currently recognised genera of Hygrotini and one subgenus are para- or polyphyletic, revealing the need of a new classification of the tribe, which will be presented in a separate paper (Villastrigo, Ribera, Manuel, Millán, \& Fery, 2017).

\section{2 | MATERIALS AND METHODS}

\section{1 $\quad$ Molecular data}

We obtained molecular data from 101 specimens of 64 species, including all four currently recognised genera of Hygrotini: Heroceras Guignot, 1950, Herophydrus Sharp, 1880, Hygrotus (with two subgenera, Hygrotus and Coelambus Thompson, 1860) and Hyphoporus Sharp, 1880 (Nilsson \& Hájek, 2017a,b; see Table S1). We used as outgroups a selection of 12 species from four genera belonging to Hydroporini, shown to be related to Hygrotini (Ribera, Vogler, \& Balke, 2008). Trees were rooted on Laccornis Gozis, 1914, considered to be outside Hydroporini and Hygrotini and in a basal position within Hydroporinae (Miller \& Bergsten, 2014; Ribera et al., 2008).

\section{2 | DNA extraction and sequencing}

Specimens were collected in the field and preserved in absolute ethanol. DNA was extracted using commercial kits (mostly DNeasy Tissue Kit, Qiagen, Hilden, Germany) following the instructions of the manufacturers. Vouchers and
DNA samples are kept in the collections of the Institute of Evolutionary Biology (IBE, Barcelona) and Museo Nacional de Ciencias Naturales (MNCN, Madrid). We sequenced fragments of seven genes in six sequencing reactions, three mitochondrial: (i) $5^{\prime}$ end of cytochrome $c$ oxidase subunit 1 (COI-5, "barcode" fragment of Hebert, Ratnasingham, \& De Waard, 2003), (ii) 3' end of cytochrome $c$ oxidase subunit 1 (COI-3), (iii) $5^{\prime}$ end of $16 \mathrm{~S}$ RNA plus the Leucine tRNA plus $5^{\prime}$ end of NADH dehydrogenase subunit I (16S); three nuclear fragments: (iv) an internal fragment of the large ribosomal unit 28S RNA (28S), (v) an internal fragment of the small ribosomal unit, 18S RNA (18S) and (vi) an internal fragment of Histone 3 (H3). Details on primers used and typical polymerase chain reaction (PCR) conditions are provided in Table S2. Sequences were assembled and edited with Geneious v6.0.6 (Kearse et al., 2012); new sequences have been submitted to the EMBL database with accession numbers LT882773-LT883126 (Table S1).

\section{3 | Phylogenetic analyses}

Edited sequences were aligned using the online version of MAFFT 7 with the G-INS-I algorithm (Katoh, Asimenos, \& Toh, 2009). For one species (Hygrotus (Coelambus) pedalis (Fall, 1901)) we pooled sequences of two specimens in a chimera to complete the data set (Table S1), after testing their monophyly with COI-3. We used PartitionFinder v1.1.1 (Lanfear, Calcott, Ho, \& Guindon, 2012) to estimate the best fitting evolutionary model initially using one partition for each gene fragment except for COI (split in COI-5 and COI3 ) and $16 \mathrm{~S}$ and tRNA (pooled in a single partition), and applied Akaike Information Criterion (AIC) scores as selected criteria.

We used BEAST 1.8 (Drummond \& Rambaut, 2007) for Bayesian phylogenetic analyses, using the partition and evolutionary models selected by PartitionFinder and a molecular-clock approach for estimating divergence times. We applied an uncorrelated lognormal relaxed clock to estimate substitution rates and a Yule speciation process as the tree prior. We calibrated the tree using rates estimated in Andújar, Serrano, and Gómez-Zurita (2012) for a genus of Carabidae (Carabus), in the same suborder Adephaga (rate of 0.0113 [95\% confidence interval 0.0081-0.0147] substitutions per site per million years (subst/s/Ma) for COI5; $0.0145[0.01-0.0198]$ subst/s/Ma for COI-3 and 0.0016 [0.001-0.0022] subst/s/Ma for $16 \mathrm{~S}+$ tRNA). Analyses were run for 100 million generations, assessing that convergence was correct and estimating the burn-in fraction with Tracer v1.6 (Drummond \& Rambaut, 2007). We also used a fast maximum likelihood (ML) heuristic algorithm in RAxMLHPC2 (Stamatakis, 2006) in the CIPRES Science Gateway (Miller, Pfeiffer, \& Schwartz, 2010), using the same partition scheme as in BEAST with a GTR + G evolutionary model 
independently estimated for each partition and assessing node support with 100 pseudoreplicas with a rapid bootstrapping algorithm (Stamatakis, Hoover, \& Rougemont, 2008).

\section{4 | Morphological data}

To estimate the likely phylogenetic relationships of the species for which no molecular data could be obtained, we studied all described species of subgenera Hygrotus and Coelambus with the only exceptions of $H$. (C.) artus (Fall, 1919), known only from the holotype and considered to be possibly extinct (see Anderson, 1983), and $H$. (C.) femoratus (Fall, 1901), which is likely a junior synonym of $H$. (C.) nubilus (LeConte, 1855) (Anderson, 1983). We have also studied a large selection of species of Herophydrus and Hyphoporus (see Table S3 for the studied material).

The taxonomic classification of Hygrotini has suffered multiple changes, and some of the characters used to define genera (such as e.g., the morphology of the clypeus) are difficult to interpret and characterise (see e.g., Anderson, 1971; Balfour-Browne, 1934; Biström \& Nilsson, 2002; Falkenström, 1933; Villastrigo et al., 2017). Species for which no molecular data were available were thus considered to be closely related to those showing a high morphological similarity, based both on external characters and on the female and male genitalia. We also recognised diagnostic characters or character combinations of the different clades of the molecular phylogeny and tested their presence in the species without molecular data (see Villastrigo et al., 2017 for more details). We used Mesquite v3.20 (Maddison \& Maddison, 2017) to manually place all species in their most likely position in the phylogenetic tree, and collapsed uncertain nodes to create polytomies.

\section{5 | Salinity tolerance data}

We compiled ecological data on habitat preferences of all species of Hygrotini from bibliography and from our own observations (Table S3). Recent work on salinity tolerance in aquatic Coleoptera has recognised six different categories of habitat preferences: (i) $\mathrm{FW}(<0.5 \mathrm{~g} / \mathrm{L})$; (ii) mineralised (0.5-5 g/L); (iii) hyposaline ( $\geq 5-20 \mathrm{~g} / \mathrm{L}$ ); (iv) mesosaline ( $\geq 20-40 \mathrm{~g} / \mathrm{L}$ ); (v) hypersaline ( $\geq 40-80 \mathrm{~g} / \mathrm{L}$ ); (vi) extreme hypersaline (>80 g/L) (Arribas et al., 2014). As quantitative observations in species of Hygrotini were very scarce we reduced these categories to three: (i) species strictly bounded to FW environments (approximately $<0.5 \mathrm{~g} / \mathrm{L}$ ), corresponding to category (i) above; (ii) species that can tolerate a wide range of salinities (approximately $0.5-40 \mathrm{~g} / \mathrm{L}$ ), corresponding to categories (ii-iv) above; and (iii) hypersaline species (approximately $>40 \mathrm{~g} / \mathrm{L}$ ), corresponding to categories (v) and (vi) above. To reconstruct the evolution of saline tolerance we pruned the data set to one specimen per species and deleted the outgroups, using salinity tolerance as a qualitative trait. This reduced matrix was analysed in BEAST using the same settings as for the phylogenetic reconstruction, with an asymmetric substitution model for the trait reconstruction and dating the ancestral node according to the results of the previous analysis (with a Gamma distribution with shape 30 and scale 2.227). We also reconstructed the evolution of saline tolerance in the extended phylogeny, including species for which no molecular data were available, using parsimony in Mesquite.

\section{3 | RESULTS}

\section{1 | Molecular phylogeny}

The best partition schemes selected by PartitionFinder pooled the two fragments of COI and several of the nuclear genes, and favoured the most complex evolutionary models for most partitions (Table 1). The topological differences between the Bayesian analysis and the ML searches were minimal and always affected poorly supported nodes (Figures 1, S1), associated with the position of three species: Hygrotus (Coelambus) fumatus (Sharp, 1882), Hygrotus (Coelambus) urgensis (Jakovlev, 1899) and Hygrotus (Hygrotus) hydropicus (LeConte, 1852). In all cases, the monophyly of Hygrotini was recovered with strong support, as were most of the internal nodes (Figures 1, S1).

In all analyses, Hygrotini was divided into two lineages (posterior probability $[\mathrm{pp}]=1$; bootstrap support $[\mathrm{BS}]=98$ ): (A) three Nearctic and one Palaearctic species of subgenera Hygrotus and Coelambus and (B) the remaining species of the tribe (Fig. 1). The latter was in turn divided into four clades: (B1) a group of Palaearctic species of subgenus
T A B L E 1 Best partition schemes and optimal evolutionary models as estimated with PartitionFinder

\begin{tabular}{|c|c|c|c|c|c|}
\hline \multicolumn{3}{|c|}{ Complete data set } & \multicolumn{3}{|c|}{ Reduced data set } \\
\hline $\mathbf{P}$ & Genes & Model & $\mathbf{P}$ & Genes & Model \\
\hline$\# 1$ & $\mathrm{COI}-5+\mathrm{COI}-3$ & $\mathrm{GTR}+\mathrm{I}+\mathrm{G}$ & $\# 1$ & COI-5 + COI-3 & $\mathrm{GTR}+\mathrm{I}+\mathrm{G}$ \\
\hline$\# 2$ & $16 \mathrm{~S}+\mathrm{NAD} 1$ & $\mathrm{GTR}+\mathrm{I}+\mathrm{G}$ & \#2 & $16 \mathrm{~S}+\mathrm{NADH}$ & $\mathrm{GTR}+\mathrm{I}+\mathrm{G}$ \\
\hline \multirow[t]{2}{*}{ \#3 } & $18 \mathrm{~S}+28 \mathrm{~S}+\mathrm{H} 3$ & $\mathrm{GTR}+\mathrm{I}+\mathrm{G}$ & \#3 & $18 \mathrm{~S}+28 \mathrm{~S}$ & GTR + I \\
\hline & & & \#4 & H3 & $\mathrm{GTR}+\mathrm{I}+\mathrm{G}$ \\
\hline
\end{tabular}

P, partition. 


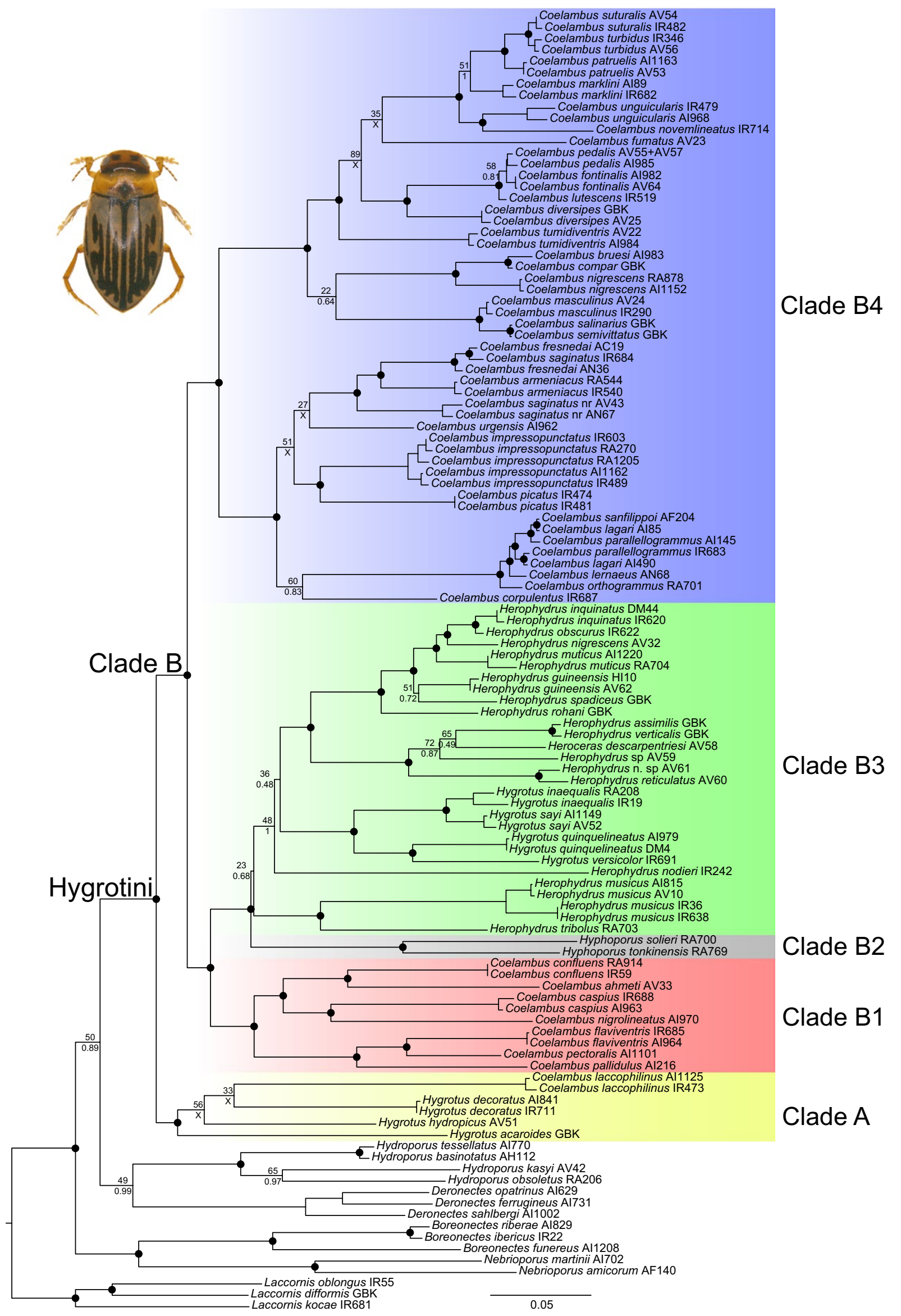


F I G U R E 1 Best maximum likelihood (ML) phylogram obtained in RAxML with the extended dataset of Hygrotini (including outgroups and multiple terminals per species). Black circles, nodes with bootstrap support in RAxML (BS) $>70$ and posterior probability (pp) in BEAST >0.95; when support values were lower: numbers above nodes, BS; numbers below nodes, pp. X, nodes not recovered in the BEAST analyses (Fig. S1). See Table S1 for details on the specimens. For clarity, only the subgenus name is given in Hygrotus s.str. and Coelambus. Habitus photograph: Hygrotus (Coelambus) lagari (Fery, 1992) (from Millán et al., 2014)

Coelambus, (B2) the two sampled species of Hyphoporus, (B3) a large group of species including Heroceras, all sampled Herophydrus and most species of Hygrotus s. str., and (B4) the remaining species of subgenus Coelambus, in turn divided into two sister clades, one with mostly Palaearctic species and a second with mostly Nearctic species.

The monophyly of all clades had strong support in both Bayesian and ML analyses except for clade B3 (Fig. 1). This clade included the genus Herophydrus as paraphyletic with respect to Heroceras and most species of the subgenus Hygrotus, the latter grouped in a monophyletic lineage. Heroceras and the sampled species of Herophydrus from Madagascar with the exception of H. spadiceus Sharp, 1882 formed a strongly supported clade $(\mathrm{pp}=1, \mathrm{BS}=100)$, in turn placed (with lower support) inside a lineage with most of the remaining sampled African Herophydrus (Fig. 1).

The internal phylogeny of the main clades was generally in good agreement with the recognised species groups among subgenera Hygrotus and Coelambus based on morphology (see e.g., Anderson, 1971, 1976, 1983; Fery, 1992, 1995, 2003), although not with the phylogeny of Herophydrus obtained by Biström and Nilsson (2002).

\section{2 $\quad$ Evolution of tolerance to salinity}

Differences between the analyses of the complete and reduced data set referred mostly to the position of Hyphoporus (clade B2). In the complete data set it was placed as sister to clade B3, and both sister to clade B1, with very strong support (Fig. 1). In the reduced data set, without outgroups and with only one terminal per species, it was placed as sister to clade B4, but with low support (Fig. 2). However, the uncertainty in the phylogenetic position of Hyphoporus (clade B2) did not have any effect on the reconstruction, as the two possible sister clades, B3 (Fig. 1) or B4 (Figures 2, S2), were reconstructed to have a FW ancestor, and thus, their common ancestor was also reconstructed as living in FW habitats.

According to the Bayesian reconstruction in the reduced data set, tolerance to salinity emerged independently from a FW ancestor at least ten times within three of the main lineages of Hygrotini: B1, B3 and B4 (Fig. 2). There were five subsequent independent transitions from tolerant to hypersaline (mainly in the Nearctic lineage of clade B4), although in some cases these transitions affected only the terminal branches in our phylogeny. Four of the transitions from FW to salinity tolerant and one of the transitions to hypersalinity led to clades with more than one species, and in only one clade
(B4) there have been three reversal transitions from tolerant to FW. No direct transitions from FW to hypersaline habitats were found in the reconstruction (Fig. 2).

The oldest transition to salinity tolerance, at the base of the clade with the highest number of saline species, was dated to the late Eocene-early Oligocene. Three of the transitions to hypersalinity tolerance were estimated to have occurred during the Oligocene, one of them with a further diversification in the early Pleistocene, including $H$. (C.) salinarius and Hygrotus (Coelambus) masculinus (Crotch, 1874; Fig. 2). Other transitions to hypersalinity tolerance affecting single species occurred in the middle Miocene (Hygrotus (Coelambus) diversipes Leech, 1966) and the Pleistocene (Hygrotus (Coelambus) fontinalis Leech, 1966; see Fig. 2).

The highest estimated transition rate was from $\mathrm{FW}$ to tolerant (1.97 transitions/branch/My [t/b/My]), followed by tolerant to hypersaline $(1.45 \mathrm{t} / \mathrm{b} / \mathrm{My}$, Table 2$)$. Direct transition from FW to hypersaline waters had the lowest rate $(0.23 \mathrm{t} / \mathrm{b} / \mathrm{My})$, even lower than that estimated for reversal from hypersaline tolerance to FW (0.37 t/b/My, Table 2$)$.

For most species without molecular data a close relative included in the phylogeny could be identified based on similarities in the genitalia or the external morphology, although in a few cases no obvious relatives could be identified, and the species were placed in an unresolved polytomy in the less inclusive clade to which they could be ascribed (Fig. S2). The parsimony reconstruction of salinity tolerance in this extended phylogeny gave similar results to the reconstruction using only the molecular data. The last common ancestor of Hygrotini was a FW species, as was the reconstructed ancestors of clades A, B2 and B3. For nodes including species with the three states of the trait, such as in clades B1 and B4, the ancestral reconstruction was ambiguous in the parsimony analysis (Fig. S2). On the contrary, in the Bayesian analysis of the reduced data set they were reconstructed as FW with a high probability (Fig. 2). Most of the tolerant or hypersaline species were included within clades with at least some other tolerant species, in agreement with the results obtained with the phylogeny using only species with molecular data (Figures 2, S2).

\section{4 | DISCUSSION}

\section{1 | Molecular phylogeny}

We obtained a robust phylogeny of Hygrotini, with good support for most internal nodes except for the monophyly of 


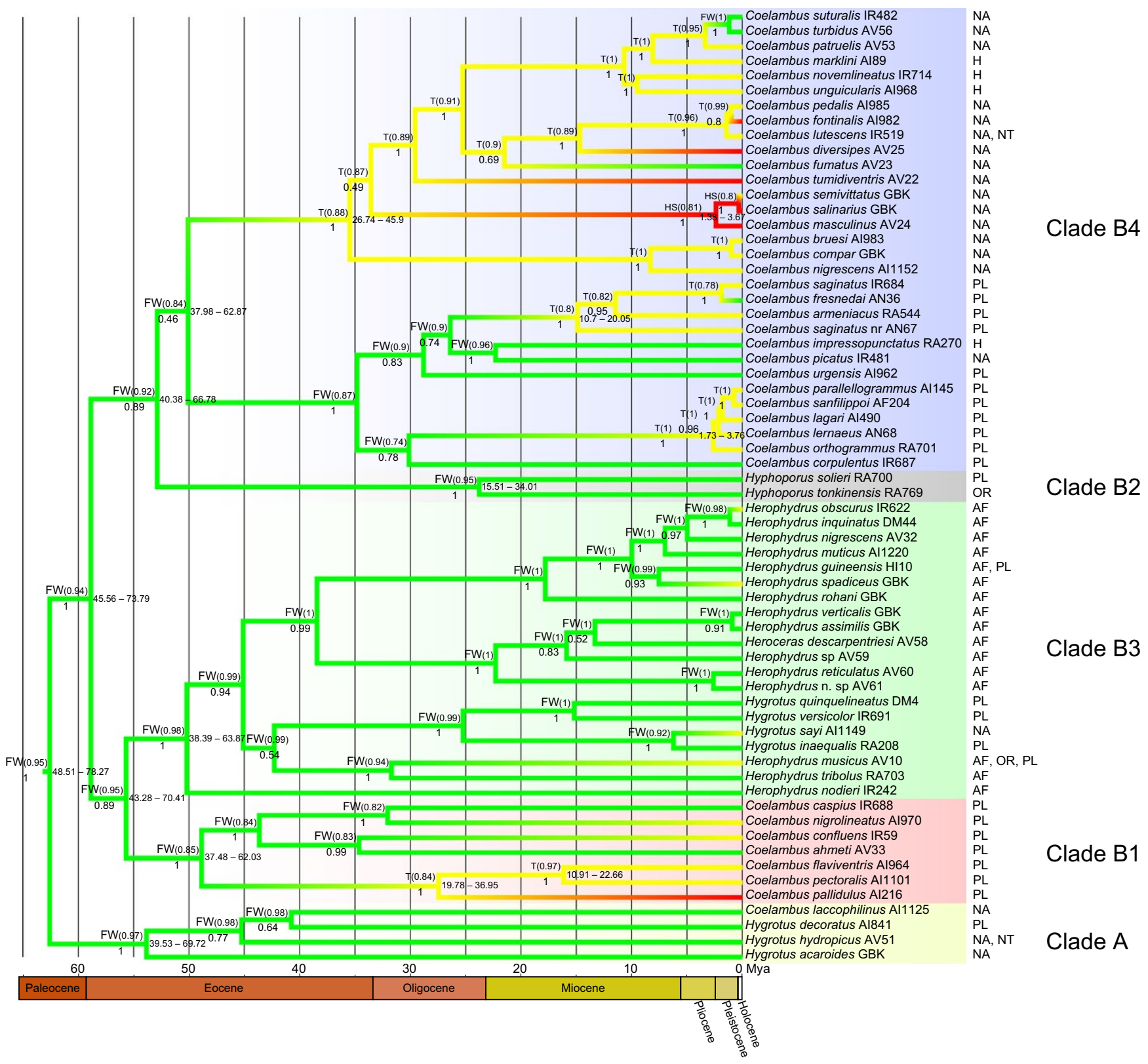

F I G URE 2 Reconstruction of the evolution of tolerance to salinity in the reduced data set of Hygrotini (excluding outgroups and with only one terminal per species) in BEAST. Letters above nodes: reconstructed state of the trait (FW, freshwater, green; T, tolerant, yellow; HS, hypersaline, red); numbers inside parentheses: posterior probability of the reconstructed discrete state; numbers below nodes: node support (pp); numbers inside nodes: $95 \%$ interval of the reconstructed age of selected nodes. For clarity, only the subgenus name is given in Hygrotus s.str. and Coelambus. See Tables S1 and S3 for details on the specimens and the ecological typification of the species, respectively. Geographic distribution: AF: Afrotropical; H: Holarctic; NA: Nearctic; NT: Neotropical (northern Mexico); OR: Oriental; PL: Palaearctic

\begin{tabular}{lccc} 
& Freshwater & Tolerant & Hypersaline \\
\hline Freshwater & - & $1.97(0.33-3.99)$ & 0.23 \\
& & - & $(<0.001-0.72)$ \\
Tolerant & $1.23(0.09-2.83)$ & - & $1.4(0.03-3.02)$ \\
\hline Hypersaline & $0.37(<0.001-1.17)$ & $0.73(<0.001-1.9)$ & - \\
\hline
\end{tabular}

T A B L E 2 Estimated transition rates in BEAST between the discrete states of tolerance to salinity

In brackets, $95 \%$ confidence interval.

clade B3 and its relationship with Hyphoporus. Our species sampling was also very dense except for Herophydrus and for Hyphoporus, of which we could obtain fresh material of only two species. These two species, however, belong to the two different morphological groups recognised in the revision of the genus by Vazirani (1969). 
The most unexpected result of our phylogeny was the deep division of Hygrotini in two clades, one of them formed by a small number of species. Despite the lack of clear synapomorphies, these species share some presumably plesiomorphic characters of body shape, colouration and male genitalia, the latter being in general simpler and more similar to those of other related tribes of Hydroporinae. The internal relationships within clade A are still poorly defined, and would need further morphological and molecular studies to be clarified. Within clade B3, the close relationships of Hygrotus s. str., Herophydrus and Heroceras had been previously noted by many authors (Abellán et al., 2013; Alarie \& Michat, 2007; Biström \& Nilsson, 2002; Miller \& Bergsten, 2014; Ribera, Hogan, \& Vogler, 2002; Ribera et al., 2008), and suggested by the (incomplete) molecular and morphological phylogenies available prior to our study. Species of Hyphoporus have always been considered to be related to the species of Herophydrus, of which they differ mostly in the male genital shape (e.g., Biström \& Nilsson, 2002; Miller $\&$ Bergsten, 2016). The non-monophyly of genera Hygrotus and Herophydrus and subgenera Hygrotus and Coelambus requires a revised classification of the tribe, which will be formalised in a separate paper (Villastrigo et al., 2017).

\section{2 $\quad$ Evolution of the tolerance to salinity in Hygrotini}

We found several independent origins for the salinity tolerance in the tribe Hygrotini, with at least 10 transitions from FW to saline ecosystems both in the Palaearctic and the Nearctic. The multiple origin of saline species was expected, as they were included in different morphologically well characterised subgenera or species groups, but the number of transitions was lower than anticipated, as some of the saline species in clade B4 that were not thought to be related (as e.g., Hygrotus (Coelambus) marklini (Gyllenhall, 1813) and $H$. (C.) salinarius) were grouped in the same monophyletic radiation. In other families of aquatic Coleoptera, species that were apparently not closely related were also found to have a common origin of their tolerance to salinity, as for example in the genera Ochthebius Leach, 1815 (Hydraenidae; see Sabatelli et al., 2016) and Enochrus Thomson, 1859 (Hydrophilidae; see Arribas et al., 2014).

We did not find any direct transition from FW to hypersaline habitats, a transition that had the lowest estimated probability, suggesting that in Hygrotini the adaptation to salinity has been a gradual process. The only possible exception was Hygrotus (Coelambus) pallidulus (Aubé, 1850), sister to a group of tolerant species, but the clade was reconstructed as having a FW ancestor with high probability. However, $H$. (C.) pallidulus together with its tolerant sisters are included in a wider lineage with several other tolerant species of which no molecular data could be obtained, rendering the condition of their common ancestor ambiguous (as can be seen in Fig. S2). This gradual evolution is in contrast to the direct transitions from FW to hypersaline tolerance found in a group of Mediterranean species of Enochrus (Arribas et al., 2014). These transitions were associated with periods of aridification of the climate, leading to the hypothesis that saline tolerance may have been a by-product (an exaptation) of adaptation to desiccation (Arribas et al., 2014; Pallarés, Velasco, Millán, Bilton, \& Arribas, 2016). The capability to produce hyperosmotic excreta is a plesiomorphic character in insects, likely linked to the necessary adaptations to a terrestrial environment (Bradley, 2008; Bradley et al., 2009; Cloudsley-Thompson, 2001). In the only species for which the salinity tolerance mechanism is known, $H$. (C.) salinarius, adults maintain a hyposmotic haemolymph also with hyperosmotic excreta (Tones, 1978), with no evidence of any additional mechanism particular to this species. However, larvae of $H$. (C.) salinarius maintain a hyperosmotic haemolymph even at high saline concentrations (Tones, 1978), suggesting a different mechanism to that of adults. Although there is an increasing knowledge of the physiological basis of salinity tolerance in adult Coleoptera (e.g., Céspedes, Pallarés, Arribas, Millán, \& Velasco, 2013; Pallarés, Arribas, Bilton, Millán, \& Velasco, 2015; Pallarés, Arribas, Céspedes, Millán, \& Velasco, 2012), the physiology of larval tolerance to salinity is still unknown. However, both the different characteristics of the cuticle (less sclerotised and without the protection of the elytra) and the biology (usually more strictly linked to the aquatic environment) suggest that the existence of different mechanisms to salinity tolerance in adults and larvae may be frequent.

In any case, it must be noted that we have data only on the ecological preferences of the species of Hygrotini, not on their physiological tolerances. If tolerance to salinity is an exaptation derived from a plesiomorphic adaptation to terrestrial environments (as hypothesised by Arribas et al., 2014; see Pallarés, Botella-Cruz, Arribas, Millán, \& Velasco, 2017 for an experimental confirmation of the link between salinity and desiccation tolerance), tolerance to at least certain degree of salinity may be widespread even in species commonly found in FW habitats, as has been demonstrated to be the case in other groups of aquatic Coleoptera (Céspedes et al., 2013; Pallarés et al., 2015). Our ecological typification was also in most cases based on qualitative descriptions, without quantitative data. For some species there are few, if any, reports on their habitat, and in some cases we have assumed a FW habitat when the information was not very precise, as when species are found in saline or hypersaline habitats this is usually reported. In some cases qualitative reports can be ambiguous, such as for example when species are considered "halophile" or "halobiont" when they occur in slightly mineralised waters in a landscape otherwise lacking any true saline or hypersaline habitat, such as for example Hygrotus 
(Hygrotus) inaequalis (Fabricius, 1777) or H. (Coelambus) impressopunctatus (Schaller, 1783) in some areas in central and northern Europe (e.g., Bellstedt, 2008).

In Hygrotini, the transitions to saline habitats were estimated to have occurred in different periods, from the late Eocene to the Plio- and Pleistocene, without a clear pattern of associations to arid periods, in contrast to what happened in the genus Enochrus in the Mediterranean region (Arribas et al., 2014). However, the oldest transition to saline habitats in Hygrotini, and the one leading to the higher number of saline species, occurred at the end of the Eocene in clade B4 in the Nearctic region, coincident with a global decrease in temperatures and the onset of the first Oligocene glaciations (Liu et al., 2009; Zachos, Pagani, Sloan, Thomas, \& Billups, 2001). In North America, this decrease in temperature was associated with a decrease in precipitation (Retallack, 2007), leaving open the possibility that this transition to saline habitats was also a response to an increased aridification in this lineage.

\section{ACKNOWLEDGEMENTS}

We would like to thank all colleagues mentioned in Table S1 for sending valuable material for study, as well as Ana Izquierdo (MNCN), Rocío Alonso and Anabela Cardoso (IBE) for laboratory work. M. Manuel is grateful to Andriamirado T. Ramahandrison for help during field work in Madagascar, in the context of the RicciaTeam expedition led by Catherine Reeb. We also thank Josefa Velasco and Susana Pallarés (Universidad de Murcia) and Paula Arribas (Instituto de Productos Naturales y Agrobiología-CSIC) for comments on the origin and evolution of salinity tolerance, and three anonymous referees for their comments and suggestions. This work was partly funded by an FPI grant to A.V., and projects CGL2013-48950-C2-1-P and CGL2013-48950C2-2-P (AEI/FEDER, UE) to I.R. and A.M., respectively.

\section{REFERENCES}

Abellán, P., Sánchez-Fernández, D., Picazo, F., Millán, A., Lobo, J. M., \& Ribera, I. (2013). Preserving the evolutionary history of freshwater biota in Iberian National Parks. Biological Conservation, 162, $116-126$

Alarie, Y., \& Michat, M. C. (2007). Phylogenetic analysis of Hydroporinae (Coleoptera: Dytiscidae) based on larval morphology, with description of first instar of Laccornellus lugubris. Annals of the Entomological Society of America, 100, 655-665.

Anderson, R. D. (1971). A revision of the Nearctic representatives of Hygrotus (Coleoptera: Dytiscidae). Annals of the Entomological Society of America, 64(2), 503-512.

Anderson, R. D. (1976). A revision of the Nearctic species of Hygrotus groups II and III (Coleoptera: Dytiscidae). Annals of the Entomological Society of America, 69(4), 577-584.

Anderson, R. D. (1983). Revision of the Nearctic species of Hygrotus groups IV, V and VI (Coleoptera: Dytiscidae). Annals of the Entomological Society of America, 76(2), 173-196.
Andújar, C., Serrano, J., \& Gómez-Zurita, J. (2012). Winding up the molecular clock in the genus Carabus (Coleoptera: Carabidae): Assessment of methodological decisions on rate and node age estimation. BMC Evolutionary Biology, 12, 40.

Arribas, P., Andújar, C., Abellán, P., Velasco, J., Millán, A., \& Ribera, I. (2014). Tempo and mode of the multiple origins of salinity tolerance in a water beetle lineage. Molecular Ecology, 23, 360-373.

Balfour-Browne, F. (1934). Systematic notes upon British aquatic Coleoptera. Part II. The Hydroporinae (Hygrotus \& Coelambus). The Entomologist's Monthly Magazine, 70, 146-150.

Bellstedt, R. (2008). Wasserkäfer \& Langbeinfliegen (aquatische Coleoptera \& Diptera: Dolichopodidae) in vier Binnensalzstellen Nordthüringens von 2005 bis 2007. Mitteilungen des Thüringer Entomologenverbandes, 15, 124-141.

Biström, O., \& Nilsson, A. N. (2002). Herophydrus Sharp: Cladistic analysis, taxonomic revision of the African species, and world check list (Coleoptera: Dytiscidae). Koleopterologische Rundschau, 72, 15-111.

Bradley, T. J. (2008). Saline-water insects: Ecology, physiology and evolution. In J. Lancaster, \& R. A. Briers (Eds.), Aquatic insects: Challenges to populations (pp. 20-35). Wallingford: CAB International Publishing.

Bradley, T. J., Briscoe, A. D., Brady, S. G., Contreras, H. L., Danforth, B. N., Dudley, R., ... Yanoviak, S. P. (2009). Episodes in insect evolution. Integrative and Comparative Biology, 49, 590-606.

Céspedes, V., Pallarés, S., Arribas, P., Millán, A., \& Velasco, J. (2013). Water beetle tolerance to salinity and anionic composition and its relationship to habitat occupancy. Journal of Insect Physiology, 59, 1076-1084.

Cloudsley-Thompson, J. L. (2001). Thermal and water relations of desert beetles. Naturwissenschaften, 88, 447-460.

Drummond, A. J., \& Rambaut, A. (2007). BEAST: Bayesian evolutionary analysis by sampling trees. BMC Evolutionary Biology, 7, 214.

Falkenström, G. A. (1933). Schwedisch-chinesische wissenschaftliche Expedition nach den nordwestlichen Provinzen Chinas, unter Leitung von Dr. Sven Hedin und Prof. Sü Ping-chang. Insekten, gesammelt vom schwedischen Arzt der Expedition Dr. David Hummel 1927-1930. 15. Coleoptera. 1. Haliplidae und Dytiscidae. Arkiv för Zoologi, 27A(1), 1-22.

Fery, H. (1992). Revision der saginatus-Gruppe der Gattung Coelambus Thomson (Coleoptera: Dytiscidae). Linzer Biologische Beiträge, 24, 339-358.

Fery, H. (1995). Ergänzungen zur saginatus-Gruppe sowie Bemerkungen zu weiteren Arten der Gattung Coelambus Thomson (Coleoptera, Dytiscidae). Linzer Biologische Beiträge, 27, 1045-1061.

Fery, H. (2003). Dytiscidae: V. Taxonomic and distributional notes on Hygrotus Stephens, with emphasis on the Chinese fauna and a key to the Palearctic species (Coleoptera). In M. A. Jäch, L. Ji (Eds.), Water beetles of China, Vol. 3 (pp. 133-193). Wien: Zoologisch-Botanische Gesellschaft in Österreich and Wiener Coleopterologenverein.

Hebert, P. D., Ratnasingham, S., \& De Waard, J. R. (2003). Barcoding animal life: Cytochrome c oxidase subunit 1 divergences among closely related species. Proceedings of the Royal Society B: Biological Sciences, 270, S96-S99.

Katoh, K., Asimenos, G., \& Toh, H. (2009). Multiple alignment of DNA sequences with MAFFT. Methods in Molecular Biology, 537, 39-64.

Kearse, M., Moir, R., Wilson, A., Stones-Havas, S., Cheung, M., Sturrock, S., ... Drummond, A. (2012). Geneious Basic: An integrated and extendable desktop software platform for the organization and analysis of sequence data. Bioinformatics, 28, 1647-1649. 
Lanfear, R., Calcott, B., Ho, S. Y. W., \& Guindon, S. (2012). PartitionFinder: Combined selection of partitioning schemes and substitution models for phylogenetic analyses. Molecular Biology and Evolution, 29, 1695-1701.

Leys, R., \& Watts, C. H. (2008). Systematics and evolution of the Australian subterranean hydroporine diving beetles (Dytiscidae), with notes on Carabhydrus. Invertebrate Systematics, 22, 217-225.

Liu, Z., Pagani, M., Zinniker, D., DeConto, R., Huber, M., Brinkhuis, H., ... Pearson, A. (2009). Global cooling during the EoceneOligocene climate transition. Science, 325, 1187-1190.

Maddison, W. P., \& Maddison, D. R. (2017). Mesquite: a modular system for evolutionary analysis. Version 3.2. Retrieved from http:// mesquiteproject.org (last access March 2017).

Millán, A., Sánchez-Fernández, D., Abellán, P., Picazo, F., Carbonell, J. A., Lobo, J. M., \& Ribera, I. (2014). Atlas de los coleópteros acuáticos de España peninsular. Madrid: Ministerio de Agricultura, Alimentación y Medio Ambiente.

Miller, K. B., \& Bergsten, J. (2014). The phylogeny and classification of predaceous diving beetles. In D. A. Yee (Ed.), Ecology, systematics and the natural history of predaceous diving beetles (Coleoptera: Dytiscidae) (pp. 49-172). Berlin: Springer.

Miller, K. B., \& Bergsten, J. (2016). Diving beetles of the world: Systematics and biology of the Dytiscidae. Baltimore: Johns Hopkins University Press.

Miller, M. A., Pfeiffer, W., \& Schwartz, T. (2010). Creating the CIPRES Science Gateway for inference of large phylogenetic trees. In Proceedings of the Gateway Computing Environments Workshop (GCE) (pp. 1-8). New Orleans.

Nilsson, A. N., \& Hájek, J. (2017a). A world catalogue of the family Dytiscidae, or the diving beetles (Coleoptera, Adephaga). Internet Version 31.I.2017. Retrieved from http://www.norrent.se and www. waterbeetles.eu (last access March 2017).

Nilsson, A. N., \& Hájek, J. (2017b). Catalogue of Palaearctic Dytiscidae (Coleoptera). Internet version 31.I.2017. Retrieved from http:// www.norrent.se and www.waterbeetles.eu (last access March 2017).

Pallarés, S., Arribas, P., Bilton, D. T., Millán, A., \& Velasco, J. (2015). The comparative osmoregulatory ability of two water beetle genera whose species span the fresh-hypersaline gradient in inland waters (Coleoptera: Dytiscidae, Hydrophilidae). PLoS ONE, 10(4), e0124299.

Pallarés, S., Arribas, P., Céspedes, V., Millán, A., \& Velasco, J. (2012). Lethal and sublethal behavioural responses of saline water beetles to acute heat and osmotic stress. Ecological Entomology, 37, 508-520.

Pallarés, S., Botella-Cruz, M., Arribas, P., Millán, A., \& Velasco, J. (2017). Aquatic insects in a multistress environment: Crosstolerance to salinity and desiccation. Journal of Experimental Biology, 220, 1277-1286.

Pallarés, S., Velasco, J., Millán, A., Bilton, D. T., \& Arribas, P. (2016). Aquatic insects dealing with dehydration: Do desiccation resistance traits differ in species with contrasting habitat preferences? PeerJ, 4, e2382.

Picazo, F., Moreno, J. L., \& Millán, A. (2010). The contribution of standing waters to aquatic biodiversity: The case of water beetles in southeastern Iberia. Aquatic Ecology, 44, 205-216.

Retallack, G. J. (2007). Cenozoic paleoclimate on land in North America. The Journal of Geology, 115, 271-294.
Ribera, I., Hogan, J. E., \& Vogler, A. P. (2002). Phylogeny of hydradephagan water beetles inferred from $18 \mathrm{~S}$ rRNA sequences. Molecular Phylogenetics and Evolution, 23, 43-62.

Ribera, I., Vogler, A. P., \& Balke, M. (2008). Phylogeny and diversification of diving beetles (Coleoptera : Dytiscidae). Cladistics, 24, 563-590.

Sabatelli, S., Audisio, P., Antonini, G., Solano, E., Martinoli, A., \& Trizzino, M. (2016). Molecular ecology and phylogenetics of the water beetle genus Ochthebius revealed multiple independent shifts to marine rockpools lifestyle. Zoologica Scripta, 45, 175-186.

Stamatakis, A. (2006). RAxML-VI-HPC: Maximum likelihood-based phylogenetic analyses with thousands of taxa and mixed models. Bioinformatics, 22, 2688-2690.

Stamatakis, A., Hoover, P., \& Rougemont, J. (2008). A rapid bootstrap algorithm for the RAxML web servers. Systematic Biology, 57, $758-771$.

Tierney, S. M., Cooper, S. J. B., Saint, K. M., Bertozzi, T., Hyde, J., Humphreys, W. F., \& Austin, A. D. (2015). Opsin transcripts of predatory diving beetles: A comparison of surface and subterranean photic niches. Royal Society Open Science, 2, 140386.

Timms, B. V., \& Hammer, U. T. (1988). Water beetles of some saline lakes in Saskatchewan, Canada. Canadian Field-Naturalist, 102, 246-250.

Tones, P. I. (1978). Osmoregulation in adults and larvae of Hygrotus salinarius Wallis (Coleoptera, Dytiscidae). Comparative Biochemistry and Physiology Part A, 60, 247-250.

Toussaint, E. F. A., Hendrich, L., Escalona, H. E., Porch, N., \& Balke, M. (2016). Evolutionary history of a secondary terrestrial Australian diving beetle (Coleoptera, Dytiscidae) reveals a lineage of high morphological and ecological plasticity. Systematic Entomology, 41, 650-657.

Vazirani, T. G. (1969). Contribution to the study of aquatic beetles (Coleoptera). V. Revision of Indian species of Hyphoporus Sharp (Dysticidae). Bulletin du Muséum National d'Histoire Naturelle, (2) 41(1), 203-225.

Villastrigo, A., Ribera, I., Manuel, M., Millán, A., \& Fery, H. (2017). A new classification of the tribe Hygrotini Portevin, 1929 (Coleoptera: Dytiscidae: Hydroporinae). Zootaxa, in press.

Zachos, J., Pagani, M., Sloan, L., Thomas, E., \& Billups, K. (2001). Trends, rhythms, and aberrations in global climate $65 \mathrm{Ma}$ to present. Science, 292, 686-693.

\section{SUPPORTING INFORMATION}

Additional Supporting Information may be found online in the supporting information tab for this article.

How to cite this article: Villastrigo A, Fery H, Manuel M, Millán A, Ribera I. Evolution of salinity tolerance in the diving beetle tribe Hygrotini (Coleoptera, Dytiscidae). Zool Scr. 2018;47:63-71. https://doi. org/10.1111/zsc. 12255 